\title{
Strengthening Citizen Participation in the Development through E-Governance
}

\author{
Krisna Puji Rahmayanti \\ Faculty of Administrative Sciences \\ Universitas Indonesia, Indonesia \\ krisnarahmayanti@ui.ac.id
}

\begin{abstract}
Recent trend toward the usage of e-governance increases the chance of public participation and engagement through this development. E-governance can be a potential tool and process that improve the effectiveness of the development. This study aims to analyze the discourses of e-governance and the usage of e-governance to increase citizen participation. This study is a review paper. The method to collect data through literature review and analysis of secondary data. This study concludes that there is positive relevance between e-governance implementation and citizen participation to development or government activities. However, there are several notes about the challenges and threat toward e g-governance implementation that may hinder the development itself.
\end{abstract}

Keywords—e-governance, citizen participation, development

\section{INTRODUCTION}

"Nowadays, democracy is driven in the world share vision when the e-governance become reality"- is the statement of The Council of Europe to define e-governance. E-governance is a global trend. It seen as a 'control revolution' toward public administration or 'computer state' which data and information used as an instrument of control. In New Leviathan, information and technology are the instrument to integrate the state through the backdoor of information management.

Earlier, governments used technology to enhance government efficiency against bounded rationality [1]. The asymmetric information was the limitation of the government process [2]. Therefore, government used technology to overcome asymmetric information among the stakeholders. Egovernance was the use of information and technology to improve the mutual relationship between government, citizens, business, and government agencies [3].

Meanwhile, e-governance can be a potential supporter to the development. Some countries use e-governance to enhance development capacity through citizen involvement [4] [5] [6] [7]. The use of e-governance in the development is a chance to improve the relationship among stakeholders in the effective and efficient method. On the other side, the limitation of the technology also emerges around the world include Indonesia [8] [9] [10] [11] [12] [13] [14].

Further issue about the use of e-governance in the development is concerning the capacity of e-governance to engage public participation and improve the innovation of the development [15] [16] [17] [18] [19] [20] [21]. Co-creation, as part of public involvement in the development, is a positive contribution to the ownership of the development, which supports the same understanding and awareness to the development. Consider the potential of public participation in the development as well as the use of e-governance to improve efficiency of the development, this study aims to discuss the potential of e-governance to improve public engagement and participation in government that eventually influence the performance of the development.

\section{METHOD}

This study is a review paper. Data collection through desk review of secondary data and theories. The analysis consists of two perspectives, firstly, about theoretical discourses about egovernment. Secondly, about the challenges and threat toward the role of e-governance in strengthening citizen participation in the development.

\section{ANALYSIS}

In the digital age, the use of ICT in the development increases. Formerly, ICT used as an information tool of development [22]. The ICT usage helped the government to store and display the development data. This development has emerged since the technology was introduced to the government. The use of technology has started to input data and display it in the more efficient and effective process.

The public demand for the effective and efficient development supports the government to use ICT in the governance process. The capability of the technology helps the government to relieve classical bureaucratic problems, such as corruption, procedural difficulty, greater transaction cost, and lots time needed. The e-governance used in Karnataka, India, was to shorten the procedure and decrease the corrupted services [23]. Although the corruption through bribes still 3\% existed but the decrease of the amount of corruption index cannot be neglected. In addition, the time needed was shorter than the former services.

In the development of e-governance, the ICT is not solely to record and display the citizen's information but also to enhance the communication. E-governance was not only processing data but also the communication data [24]. There is a shift in the form of e-governance from intranet to the internet, which enhanced communication and interaction from 
all the stakeholders. In respect to this concept, two ways of communication in the e-governance are not only providing the information but also attracting the participation. E-governance without public engagement and participation is only the tools of data processing.

The increasing role of e-governance in the development pointed to support greater interaction between government and citizens [25]. The interaction between Members of Parliaments increased through the increasing number of interaction in the house of parliament's website [26]. Formerly, the Member of Parliament website was only providing information related to the duties. The citizens demanded greater interaction with the Member of Parliament, so some states in the US improved the website to more interactive ${ }^{[27] .}$

The case of Indonesia mentioned as one of example of the increasing of participation through e-governance. The increase usage of internet and the increase of public expectation support many digital campaigns. A study found that local leadership that come from local organizations (business, NGOs or government) become catalyst of initiatives [28].

Some studies classified the participation into different terminology of the level [29] [30]. However, there is the same tendency, which carries out in the theories that the lowest level of participation is information. It is participation although the relation between two sides only providing information. The greater participation in the process is shown not only by participating through information transfer, but also involved feedback of the provided information. It means that there is interaction. The highest participation level will influence each other, for example, the citizen's participation influences the decision making of the political process.

Further discussion about participation is about the impact and sign of the level of participation. Some studies argued that the greater participation illustrated a successful development [31] [32]. However, the greater participation is not always the sign of positive condition. A study about participation of citizen with Member of Parliament in Australia found that the greater participation in the process was caused by distrust to the government, so they complained to the politician through e-governance ${ }^{[33]}$. This study cannot be generalized but reflects that the greater participation is not always the sign of positive condition.

Therefore, the greater participation and engagement that illustrate the awareness of the citizens cannot be solely the only factor used to evaluate the development. Systemic evaluation to the performance of the development should be provided to make the full screen of the context. Moreover, the greatest participation of the citizens may hinder the development because it causes chaotic condition. Therefore, monitored, and systemic participation should be established along with the improvement of the development performance in the other sectors.

The next discussion aims to answer the challenge of egovernance as catalyst of citizen engagement. The discussion about the development of e-governance and its potential to enhance citizen's engagement and participation are a current issue in the development and e-governance. Some studies argued that e-governance potentially increased the greater engagement and participation from the citizens in the development [34] [35] [36] [37] [38] [39]. In the case of the website, the citizen may have enough information about the development process. The higher level of participation will support the citizen to interact with people from the same preference. This condition supports them to embark their voice through grassroots discussion or even greater through interaction with the decision maker. This illustrates that e-government can be a tool, interaction place, and systemic and transformative change leverage.

The emerging of the variation of ICT in the e-governance enriches the ability of e-governance as a tool of citizen's engagement and participation. Website is the common place to dig the information of the development process [40] [41]. Most of all government agencies and donors provide the information as well as interactive options in their website. The development of the social media also becomes a tool and the commonplace of the delivery of information and discussion [42]. Recently, the decision maker or event government and donor agency provides information of development through the website and simple interactive thumbnail through Facebook Page or Twitter account, which open the deliberate discussions, comments, and feedbacks from the open society in the social media. Furthermore, the development of technology may result the High-Tech service system such as pooling information though short message system, tracking crime report, and so on.

In addition, the development of ICT is not only as a tool of interaction but also the place of the interaction process. The interaction strengthens the engagement of the people because participation evoke and signify the people involvement [43]. Sharing knowledge between people in the e-governance may enhance the capability among people to shape and reshape the action. The engagement and participation in e-governance is not only bottom up (people aspiration) but also top down (government's information). The greater participation ensures the voice of people become an influence which affect the development.

Moreover, the e-governance through high tech ICT development seems as a transformative and systemic change in development. The development of ICT influences the changing level of participation and engagement. The government attract the citizen to open the website to send the development information [44]. The people will easier to understand which part they can take a role, such as individual role in the social movement and high technology participatory report. In this respect, the participation and engagement of people change differently from the time before ICT emerged in the development. E-governance is transformative and systemic change because it shifts the model of engagement and participation. It also causes the change of the development nature and influencing factors which should be provided.

The nature of the citizen's engagement and participation in the digital age may result the question related to the development. Based on the development of the ICT and the common trends in the e-government studies and implementation, the e-governance should be potentially 
influencing the greater citizen's engagement and participation in the development. The ICT offers effectiveness and efficiency of the development process with timeless and costless process [45]. The e-governance also offers many options that can be improved to enhance the development based on the local context successfully.

However, the implementation of e-governance often failed to enhance the engagement and participation in the development. The discussion of the failure of e-governance which underlined two factors behind it, lack of e-readiness and design-reality gaps [46]. Readiness of the governance based on ICT is a common issue in develops or developing countries, but the case in developing countries could be more extreme. There are some factors, which strengthen the readiness of the ICT usage in the governance such as data system infrastructure, legal infrastructure, institutional infrastructure, human infrastructure, technological infrastructure, leadership, and strategic thinking [47].

The condition in developing countries can be worse because budget constraints often limit the high cost of egovernment implementation. Moreover, the political will and hybrid leader are rare to be found. In develop countries, ereadiness can be better because they have higher resources even e-readiness keeps emerging in develop countries. From the Australia case study found that the age of citizens influences the behavior of the people participation in relation with the interaction between the Member of Parliament and the people [48]. Old people prefer to use the classical model of interaction such as a letter than to send an email.

Moreover, the gap between design and reality is the next problem in the implementation of e-governance in the development. At least there are three gaps between design and reality, hard-soft gaps, private-public gaps, and country gaps. The higher gaps cause higher possibility of failure [49]. It is rational considering that the design is the blueprint of implementation, so the plan may be different with the implementation because of certain factors. The gap illustrates the lack of e-readiness in the implementation. Furthermore, the design that is not appropriate with the local value can also become the reason. Therefore, the local model for egovernment is needed. It may increase not only the possibility of success, but also the ownership from the citizens.

Studies of the e-governance, participation, and development support the positive relation between them. However, there is still interesting discussion about some aspects in the relation between e-governance and participation in the development. Firstly, the implementation of egovernance should be driven whether based on local values or international best practices. The common issue of the development relies on the focus of the development based on local wisdom than focus on international best practices. The failure of the design and realities gap is behind that, although the definition about local values seems to be debatable. The determination between local or global values often leads to the misunderstanding of the local context itself.

Secondly, the discussion whether implementation of egovernance is run by partial or systemic actions. The high cost of the systemic implementation often becomes a reason behind the use of partial action of the e-governance implementation in developing countries. The use of e-governance tends to be departmental or local government based than national policy to maintain the budget and political will constraints. However, develop or developing countries should consider systemic strategy although the implementation uses partial/departmental approach because it can keep the development in the same synergy and purpose.

Thirdly, the discussion about inside or outside government actors drives the implementation of e-governance in development. In the case which political will difficult to drive the use of e-governance in development, private sector, civil society, and donors are the actors who drive the development. The greater role outside actor results the question about the significant impact of the use of e-governance in development. There is growing need a hybrid leader which able to understand all situations. However, it is difficult to find a hybrid leader whether from inside or outside governments.

Fourthly, digital divide is also common problem in the implementation of the e-governance in development. The lack of skills, knowledge, infrastructure, and political will are the barriers which often limit the participation [50]. E-readiness also takes part in the digital divide because it can make inclusive group more inclusive. Korean central government proved that the deployment of the e-government public service was one finding in the e-government problems related to the digital divide and e-readiness [51].

Fifthly, the people engagement and participation influence toward development. The high technology of e-governance ensures the people interact with the agent of development. The follow up action of agent of development will determine the decision of the development. However, the public aspiration is not directly influence the decisions. Although there is growing recognition of the citizen's engagement, but the decision often tends to be one or two stakeholder's interests [52]. In some cases, the technical barriers and political will often make the citizen control in the development is difficult or seems only a utopia [53]. The state as the agent of development traditionally tends to large and slow moving to the need of people [54]. For example, Albanian Party have website, but those pages tend to be a 'accessory' rather than efficient mean of communication [55].

\section{CONCLUSION}

The discussion about e-governance, participation, and citizen's engagement supports a positive sign of the development. The development can be accelerated through egovernance. The remaining issue related to the starting point to enhance the positive potential in the e-governance usage. Considering barriers in the usage of e-governance in development, political will of the leaders in all government agencies is the most important. The leader is the appropriate agent of change to drive the development through participative development. The usage of ICT in development may enhance 
citizen's co-creation of the development value, which can be a potential driver in the development.

\section{REFERENCES}

[1] Yildiz, M. (2007). E-Government Research: Reviewing The Literature, Limitation, and Ways Forward. Government Information Quartely, 646665.

[2] Simon, H. (1965). Administrative Behavior: A Study of Decision Making process in Administration Organization. New York: Free Press.

[3] The World Bank. (2004, August). Building Blocks of E-Government: Lesson from Developing Countries. Prem Notes Public Sector No 91.

[4] Chan, C., \& Pan, S. (2008). User Engagement in E-Government Systems Implementation: A Comparative Case Study of Two Singaporean EGovernment Initiatives. Strategic Information System - Elsevier, 124139.

[5] Goldfinch, S., Gauld, R., \& Herbison, P. (2009). The Participation Divide? Political Participation, Trust in Government, and E-Government in Australia and New Zealand . Australian Journal of Public Administration, 333-30.

[6] Jaeger, P. T., \& Thompson, K. M. (2003). E-Government Around The World: Lessons, Challenges, and Future Directions. Government Information Quarterly, 389-394.

[7] Park, S., Cjoi, Y.-T., \& Bok, H.-S. (2013). Does Better E-Readiness Induce More Use of E-Government? Evidence From The Korean Central E-Government. International Review of Administrative Sciences - Sage, 767-789.

[8] Puspitasari, L., \& Ishii, K. (2016). Digital divides and mobile Internet in Indonesia: Impact of smartphones. Telematics and Informatics, 33(2), 472-483.

[9] Wamuyu, P. K. (2017). Bridging the digital divide among low income urban communities. Leveraging use of Community Technology Centers. Telematics and Informatics.

[10] Kyriakidou, V., Michalakelis, C., \& Sphicopoulos, T. (2011). Digital divide gap convergence in Europe. Technology in Society, 33(3), 265270 .

[11] Sujarwoto, S., \& Tampubolon, G. (2016). Spatial inequality and the Internet divide in Indonesia 2010-2012. Telecommunications Policy, 40(7), 602-616.

[12] Okunola, O. M., Rowley, J., \& Johnson, F. (2017). The multidimensional digital divide: Perspectives from an e-government portal in Nigeria. Government Information Quarterly.

[13] Philip, L., Cottrill, C., Farrington, J., Williams, F., \& Ashmore, F. (2017). The digital divide: Patterns, policy and scenarios for connecting the 'final few'in rural communities across Great Britain. Journal of Rural Studies

[14] Nishijima, M., Ivanauskas, T. M., \& Sarti, F. M. (2017). Evolution and determinants of digital divide in Brazil (2005-2013). Telecommunications Policy, 41(1), 12-24.

[15] Naik, G., Joshi, S., \& Basavaraj, K. P. (2012). Fostering inclusive growth through e-governance embedded rural telecenters (EGERT) in India. Government Information Quarterly, 29, S82-S89.

[16] Bhuiyan, S. H. (2011). Modernizing Bangladesh public administration through e-governance: Benefits and challenges. Government Information Quarterly, 28(1), 54-65.
[17] Thomas, P. (2009). Bhoomi, Gyan Ganga, e-governance and the right to information: ICTs and development in India. Telematics and Informatics, 26(1), 20-31.

[18] Masiero, S. (2015). Redesigning the Indian food security system through e-governance: The case of Kerala. World Development, 67, 126-137.

[19] Dash, S., \& Pani, S. K. (2016). E-governance paradigm using cloud infrastructure: Benefits and challenges. Procedia Computer Science, 85, 843-855.

[20] Meijer, A. (2015). E-governance innovation: Barriers and strategies. Government Information Quarterly, 32(2), 198-206.

[21] Llantos, O. E. (2017). Cloudification of my. eskwela for e-Governance in Philippine Education. Procedia Computer Science, 109, 680-685.

[22] Heeks, R. (2001). Understanding E-Governance for Development. The Commonwealth Network

[23] The World Bank. (2004, August). Building Blocks of E-Government: Lesson from Developing Countries. Prem Notes Public Sector No 91

[24] Op.cit

[25] Ibid.

[26] Ferber, P., Foltz, F., \& Pugliese, R. (2003). The Politics of State Legislature Web Sites: Making E-Government More Participatory. Bulletin of Science, Technology, \& Society, 157-167.

[27] Ibid.

[28] Abud, M. (2012). Indonesia: New Digital Nation?. Internews, www. internews.

org/sites/default/files/resources/Internews_Indonesia_DigitalNation_201 2-07. pdf. Viewed on, 1.

[29] Cornwall, A. (2008). Unpacking 'Participation': Models, Meaning and Practices. Community Development Journal, 269-283.

[30] Arnstein, S. (1969). A Ladder of Citizen Participation. Journal of the American Institute of Planners, 216-224.

[31] Goldfinch, S., Gauld, R., \& Herbison, P. (2009). The Participation Divide? Political Participation, Trust in Government, and E-Government in Australia and New Zealand . Australian Journal of Public Administration, 333-30.

[32] Chan, C., \& Pan, S. (2008). User Engagement in E-Government Systems Implementation: A Comparative Case Study of Two Singaporean EGovernment Initiatives. Strategic Information System - Elsevier, 124139.

[33] Op.cit

[34] The World Bank. (2004, August). Building Blocks of E-Government: Lesson from Developing Countries. Prem Notes Public Sector No 91.

[35] Heeks, R. (2001). Understanding E-Governance for Development. The Commonwealth Network

[36] Jaeger, P. T., \& Thompson, K. M. (2003). E-Government Around The World: Lessons, Challenges, and Future Directions. Government Information Quarterly, 389-394.

[37] Haider, H. (2011). Helpdesk Research Report: Social Media and Reform Networks, Protests, Social Movement and Coalitions. GSDRC.

[38] Baldwin, J., Gauld, R., \& Goldfinch, S. (2011). What Public Servants Really Think of E-Government. Public management Review , 105-127.

[39] Willoughby, M., Gomez, H., \& Lozano, M. (2009). Making EGovernment Attractive. Springer, 49-62.

[40] Ferber, P., Foltz, F., \& Pugliese, R. (2003). The Politics of State Legislature Web Sites: Making E-Government More Participatory. Bulletin of Science, Technology, \& Society, 157-167.

[41] Goldfinch, S., Gauld, R., \& Herbison, P. (2009). The Participation Divide? Political Participation, Trust in Government, and E-Government 
in Australia and New Zealand. Australian Journal of Public Administration, 333-30.

[42] Haider, H. (2011). Helpdesk Research Report: Social Media and Reform Networks, Protests, Social Movement and Coalitions. GSDRC.

[43] Cornwall, A. (2008). Unpacking 'Participation': Models, Meaning and Practices. Community Development Journal, 269-283.

[44] Willoughby, M., Gomez, H., \& Lozano, M. (2009). Making EGovernment Attractive. Springer, 49-62.

[45] Heeks, R. (1999). Reinventing Government in The Information Age. (R. Heeks, Ed.) London: Routledge.p.18

[46] Ibid

[47] Ibid

[48] Goldfinch, S., Gauld, R., \& Herbison, P. (2009). The Participation Divide? Political Participation, Trust in Government, and E-Government in Australia and New Zealand. Australian Journal of Public Administration, 333-30.

[49] Op.cit

[50] Ibid

[51] Park, S., Cjoi, Y.-T., \& Bok, H.-S. (2013). Does Better E-Readiness Induce More Use of E-Government? Evidence From The Korean Central E-Government. International Review of Administrative Sciences - Sage, 767-789.

[52] Rowley, J. (2011). E-Government Stakeholders - Who Are They and What Do They Want? International Journal of Information Management - Elsevier, 53-62.
[53] Heeks, R. (1999). Reinventing Government in The Information Age. ( $\mathrm{R}$. Heeks, Ed.) London: Routledge.p.32

[54] Willoughby, M., Gomez, H., \& Lozano, M. (2009). Making EGovernment Attractive. Springer, 49-62.p.50

[55] Nune, A. (2003). The Internet and Albania: A Paradoxical Ambivalence? Sofia: Southeast European Media Center. 